\title{
Work, discretion and learning: Processes of learning and development at work
}

\author{
Stephen Billett, Griffith University, Australia
}

Billett, S (2015) Work, discretion and learning: Processes of learning and development at work, International Journal of Training Research 13 (3): 214-230

\begin{abstract}
Knowing how adults learn through work is central to understanding their development across working lives. This paper uses data about work and learning from a large national survey, to validate, elaborate and extend findings from earlier qualitative enquiries into learning through work conducted by the author. The descriptive quantitative analysis indicates informants refer to learning through their everyday work activities occurring more frequently, than when being guided by more experience co-workers, experts or supervisors. Also identified are the pedagogic potential of work in terms of work discretion and kinds of problem-solving available for these workers. Yet, these opportunities for learning are distributed asymmetrically on the bases of indicators such as levels of education, age, occupational status and working in particular occupations and industry sectors. Much of what is proposed within earlier qualitative inquiries is upheld here, but advanced further through evidence about how opportunities for working and learning are distributed.
\end{abstract}

Keywords

Work life learning, PIIAC data, quantitative analysis, everyday learning experiences, guided learning, problem-solving, workplace discretion, workplace affordances, education levels, worker age, workplace learning

\section{Work and learning}

Knowing how adults learn through work is central to understanding their development across working lives. That development is important for their personal work life trajectories, and ability to contribute, sustain and advance the interests of their work and workplace, and collectively to the economic and social viability of their communities and nations. In this way, individuals' learning and development across working life is important for personal, workplace, community and national imperatives(Organisation for Economic Co-operation and Development, 2006). Much research has been undertaken into learning through work, yet much of it (like this author's) is from a qualitative orientation and often provides detailed accounts of relatively small samples of data about individual workers' learning and development. Trends or patterns identified in such studies have been used to draw out some specific findings and makes particular conclusions (Billett, 2001; Eraut, 2004; Rainbow, Fuller, \& Munroe, 2004; Tynjala, 2008). However, this approach to inquiry fails to generate accounts that can appraise how those trends and patterns extend across different kinds of work, workers, occupations or workplaces (i.e. generalizability and particularity). Such a goal is important if accounts about learning through work are used to inform both policy and practice to promote learning across working lives. This task necessitates drawing on data from larger samples to identify such findings. Accordingly, this paper compares findings drawn from descriptive analyses of the Australian Programme for the International Assessment of Adult Competencies (PIAAC) data 
(Australian Bureau of Statisics, 2013), with those advanced through the author's earlier qualitative enquiries.

The case made here commences by initially considering how individuals are reported learning across working lives from some earlier accounts. The kinds of goal-directed activities and interactions in which they engage are held to be central to individuals' learning and those in workplaces are no exception. These are used as a platform for the analysis conducted here. Then, the approach adopted in engaging with the Australian PIIAC data is outlined and discussed. Analyses of measures associated with discretion in workplace and problem-solving activities of the kinds likely to be generative of rich learning are then presented and discussed. In this way, the characteristics of activities that are potentially pedagogically-rich are identified and discussed. It is held that workers able to engage in those kinds of activities are likely to be afforded greater opportunities for theses rich learning experiences. Also, the reporting of instances support for learning are compared with those in which individuals' learning is reported as being largely personally-mediated. In preview, the quantitative findings reinforce and extend those from the qualitative inquiries about how different kinds of work afford opportunities for individuals' learning and the likelihood of workplaces supporting that learning across the workforce. Workers in jobs with high discretion, often those in high status occupations, for instance, engage in work activities that are most likely to be generative of new and rich learning, as are some self-employed informants. So, some forms of work and kinds of occupations are potentially more likely to afford opportunities for securing new learning and being supportive of workers' development than others. Moreover, contributions of learning through work across working life are held as being far more frequent than instances of being guided, supported or taught by others. Hence, these findings emphasise the centrality of workers' learning as shaped through their discretion and problem-solving, for instance, which was identified in earlier qualitative studies. However, what the descriptive quantitative data suggest is that opportunities to engage in those kinds of work activities are distributed asymmetrically, with factors such as educational achievement, occupational status and the kinds of work undertaken. So, whilst the quantitative analysis upholds the qualitative findings, this analysis offers new findings about the distribution of opportunities across a larger cohort of workers informants, kinds of work and occupations.

Learning and development at work and through working life

Initially, it is necessary to outline what is meant here by learning and development so that the following discussion can progress based on these precepts. Learning here is seen as being something which arises all of the time and every day as individuals engage in thinking and acting (Billett, 2014b; Gauvain, 1993; Guberman \& Greenfield, 1991; Lave, 1993; Rogoff \& Lave, 1984). That learning is not a special or hybrid process. Nor is it one requiring or being reliant on intentional educational programs, there alone institutions whose central role it is to promote particular learning outcomes (Mayer, 1992). Instead, learning is both the process and legacy of humans' constant and on-going engagement in activities and interactions(Rogoff \& Lave, 1984; Scribner, 1985a). It is the momentby-moment process comprising individuals' construal of what they experience and their construction of responses to that experiencing(Reber, 1989; Valsiner, 2000). This learning process is referred to as micro-genetic development (Scribner, 1985b) or moment-by-moment learning arising through the exercise of humans' cognitive, sensory and affective capacities as they engage with what they experience (Billett, 2009; Rogoff \& Lave, 1984). Depending upon what individuals know, can do or value, this process of experiencing can comprise variously the reinforcement, or honing, or 
refinement of what they know, or what is new or novel learning for them. The kind of experiencing is dependent upon the degree by which what is experienced is either familiar or novel to individuals. Hence, the learning process is person-dependent by degree, and personally-mediated (Billett, 2014a). That person dependence is premised on individuals' ontogenetic development (i.e. what they know, can do and value) as a result of the experiences they have had pre-mediately or prior to the immediate experiencing through which they learn (Gergen, 1994; Valsiner \& van der Veer, 2000). Hence, considerations of individuals' development are necessarily separate from, yet inherently linked to their learning. Also, individuals' particular capacities, values and intentions shape what they experience and learn in person dependent ways. This person-dependency arises from experiences across the life course referred to as ontogenetic development (Scribner, 1985b), whose form and legacy are individuals' knowledge and knowing. Given the personally-premised set and sequencing of experiences and bases for engaging with them across individuals' life histories, that development is personally specific by degree(Valsiner, 2000). Hence, there can be no certainty that individuals' encountering the same activities and interactions will lead to common outcomes (i.e. learning). Instead, individuals' ontogenetic development, including their interest in even engaging with what is experienced, will shape what they learn (Billett, 2003). So, it is important to separate out the concept of learning, as a moment-by-moment experience, from their development as a collective legacy of that learning, but also shapes it.

It follows, understanding learning and development across working lives necessarily requires a consideration of both experiences and experiencing; and the relations between the two. Inquiries into this learning often focus on one or the other of those contributions. Typically, much emphasis is given to what is afforded individuals by the social and physical circumstances in which they act. Socially-based theories tend to privilege social forms and suggestions, and erroneously conclude it is possible to predict learning outcomes from what is afforded individuals (Marsick \& Watkins, 1990). Within such accounts, it is sometimes suggested that particular workplaces are restrictive or expansive (Engestrom, 1993; Fuller \& Unwin, 2004). Yet, this emphasis on what is afforded by workplaces alone denies one of the two elements of the duality that constitutes human learning and development. That is, how individuals construe and construct experiences, and how they come to engage in and learn through those experiences (Wertsch, 1998). To suggest otherwise is to position experiences as being objective, irresistible and determinant in the narrowest of behavioural (Bijou, 1990) and social deterministic accounts (Ratner, 2000). Others, privilege how individuals' comes to construe and construct what they experience (Schutz, 1996), and while this is helpful, it may not fully account for what has been afforded them. Hence, both sets of accounts and the relations between them (Billett, 2006) need to be accounted for in proposing how learning arises through their work and across their working lives.

\section{Considering work activities and their potential to promote learning}

Central to individuals' learning and development in their work and across their working lives, as outlined above, are the kind of activities and interactions in which they engage. The degree of discretion they have to make decisions about their work requires incites a range of factors, making judgements, enacting selected procedures and monitoring their progress and making judgements about their veracity. These kinds of processes mediate the potential richness of individuals' learning (Greeno \& Simon, 1988; Shuell, 1990). Similarly, problem-solving and learning are commonly held to be synonymous (J R Anderson, 1993; Glaser, 1989; Newell \& Simon, 1972; Rogoff \& Gauvain, 1984). The construction of a problem space (i.e. where a problem is identified and its characteristics 
considered, responses generated and appraised in terms of their suitability, cost, likely outcomes and viability) and their goal-directed actions have legacies that by any other name are learning (Shuell, 1990). Problem-solving that is routine or familiar for individuals likely leads to the reinforcement and refinement of what they know, whereas non-routine problem-solving is generative of new knowledge(Rogoff, 1990; Voss, 1987). So, when considering the potential for learning through work activities and interactions it is helpful to capture the kinds of activities individuals engage in and from this make judgements about their learning potential given the kinds of active engagement that they require (i.e. decision-making, appraising, routine and non-routine problem-solving).

So, more than seeking to identify activities that are intentionally enacted to support learning (i.e. interactions with more experienced workers) it is necessary to account for the kinds and qualities of activities that comprise individuals' everyday work activities. Hence, the concern here is to understand the pedagogic potential of the work activities and interactions in which individuals engage and from which they learn. From this platform of precepts, it is possible to make judgements about the degree by which work activities likely generate learning and whether that learning is restricted to the honing and reinforcement and revision of what individuals already know, can do and value, or whether it is about extending or even transforming these capacities

A series of studies across a range of workplaces, in diverse industries and with workers of different kinds identified the importance of the workplace as a site for learning, by, in particular, gathering data from workers who had largely learnt their occupational capacities in and through their work (Billett, 2001). What these studies concluded was that much of that learning arose outside of close guidance of more experienced co-workers. Engagement in goal-directed activities, observing and listening to others, opportunities to practice, all of which comprise personallymediated processes stood alongside direct contributions from more experienced workers. Moreover, it was event that the kinds of work activities and interactions individuals engage in had direct consequences for their learning. However, these findings arose from qualitative studies that relied upon detailed account form interviews, critical incidents and observations of work and workers. So, whilst detailed they lacked the quantum of responses that could be used to claim with any confident that these findings had applicability beyond their source, or that there might be different patterns of finding across industry sectors or forms of work.

Therefore, to compare with what has been found in earlier qualitative inquiries, it necessary to verify and substantiate these findings from broader range of sources. Consequently, the opportunity provided by the PIAAC data is to identify the kinds of work activities in which individuals report engaging by drawing upon a large data set, which includes responses to items about work discretion, problem-solving and processes of learning.

\section{Approach to inquiry}

The Survey of Adult Skills was conducted in 33 countries to measures the cognitive and workplace skills needed to participate in contemporary working life. This survey is part of the PIAAC survey in which Australian adults participated in 2011-2012 and whose first findings were published in 2013 (Australian Bureau of Statisics, 2013). Here, data from the PIAAC survey pertaining to aspects of: i) work discretion, ii) opportunities for engaging in problem-solving activities and iii) learning in workplaces are used to identify patterns of opportunities for learning through work.

The survey instrument was designed and trialled and promoted through the OECD, and is configured to comprise measures, processes and factors that are country-dependent, but also can 
be compared across countries. The Australian data was gathered in 2011, using the survey instrument as undertaken by trained interviewers, who conducted computer-assisted personal interviews with informants. A series of screening questions were used to identify informants who were in the scope of those to be interviewed. Once selected, respondents were asked to respond to a series of background questionnaire items about their education, vocational training, employment, incomes and skill use in literacy, numeracy and information and communication technologies.

Subsequently, they responded to detailed questions about their work and these data are drawn upon here. In Australia, the sampling was designed to provide reliable estimates at national and state/territory levels. The initial sample comprised over 14,000 respondents of which about 11500 remained in the survey and 8446 responses had sufficient data for their scores to be used. However, when the ABS data was converted to align with parameters for international comparisons (e.g. aligned with age groups), the final sample was 7430 , and because not all informants were asked all questions, some items had only 5500 respondents. Yet, despite their reduced numbers, these informants offer a substantial body of carefully gathered data were incomplete or error-ridden data has been excluded. It is these data that are drawn upon here that are used descriptively.

The means of analysis were as follows. The survey items were reviewed and those pertaining to aspects of work that that could be aligned with learning were selected for analyses, as were two that explicitly referred to learning through work. The items for discretion at work are as follows:

To what extent can you choose or change:

the sequence of your tasks?

how you do your work?

the speed or rate at which you work?

The responses for each item were the same: Not at all (1); Very little (2); To some extent (3); To a high extent (4) and To a very high extent (5)

The items associated with problem solving were:

How often are/were you usually faced by relatively simple problems that take/took no more than 5 minutes to find a good solution?

How often are/were you usually confronted with more complex problems that take/took at least 30 minutes to find a good solution?

The interviewers reminded informants that the ' 30 minutes only' refers to the time needed to identify a solution, not the time needed to enact it. The responses provided for both scenarios were: Never (1); Less than once a month (2); Less than once a week, but at least once a month (3); At least once a week but not every day (4) and Every day (5).

The items selected associated with learning through work were:

In your own job, how often do you learn new work-related things from co-workers or supervisors?

How often does your job involve learning-by-doing from the tasks you perform?

The responses provided for both scenarios were: Never (1); Less than once a month (2); Less than once a week but at least once a month (3); At least once a week but not every day (4) and Every day (5). The instructions to interviewees for the first question include the following statement: If the respondent has no co-workers or supervisors, the answer should be 'never'.

These items were analysed descriptively by SPSS statistical analysis software using a common set of variables constituting some background data for the survey as variables: i) gender; ii) categories of age; iii) industries in which informants were employed; iv) their occupations; v) level of educational achievement and vi) occupational status. In the sections below, two sets of findings associated with learning, firstly through work activities, and then through accounts of that learning are presented and discussed. The descriptive approach was adopted and the use of frequencies, and 
relatively simple for three reasons. Firstly, the descriptive approach was that which was most reasonably able to be aligned with the kinds of analyses undertaken in qualitative studies, where frequencies of responses from critical incidents were used to identify the contributions of workplace factors. Secondly, the sample size is significant and the analyses undertaken here inevitably drew upon the entire data set, thereby drawing upon a large amount of responses. Thirdly, such a large body of data will inevitably lead to indications of significance in most of these kinds of analyses, which are often quite unhelpful. Complex statistical procedures would be required that take the analysis away from the kind being sought here.

Findings associated with discretion within work activities

As noted above, decision-making, problem-solving and the scope thereof, are well aligned with opportunities for learning (J R Anderson, 1993; Shuell, 1990). Hence, the extent of discretion is indicative of opportunities individuals are afforded for learning. Yet, what is evident in the analysis here is the asymmetrical ways opportunities are distributed across this large sample. Table 1 presents data about the extent discretion is afforded on basis of gender and age, comprising the mean, from a possible score of 5 , across responses to informants' ability to: i) choose the sequence of work tasks; ii) change main work tasks; and iii) change the pace of work. In terms of gender, there is not much difference reported between male and female in terms of their abilities to choose the sequencing of work tasks. Males report a slightly higher average to change main work tasks and pace of that work. These differences only constitute a small percentage of the standard deviation.

Table 1 Task discretion by Gender and Age

\begin{tabular}{|c|c|c|c|c|c|c|c|c|c|c|}
\hline & & \multicolumn{9}{|c|}{ Task discretion } \\
\hline & & \multicolumn{3}{|c|}{$\begin{array}{c}\text { Extent to which you can } \\
\text { choose the sequence of } \\
\text { your work }\end{array}$} & \multicolumn{3}{|c|}{$\begin{array}{l}\text { Extent to how you can } \\
\text { change main work tasks }\end{array}$} & \multicolumn{3}{|c|}{$\begin{array}{c}\text { Extent to which you can } \\
\text { change the pace of your } \\
\text { work }\end{array}$} \\
\hline & & means & se & $\mathrm{Sd}$ & means & $\mathrm{Se}$ & $\mathrm{Sd}$ & means & se & $\mathrm{sd}$ \\
\hline \multirow[t]{2}{*}{ Gender } & Male & 3.34 & 0.02 & 1.22 & 3.30 & 0.02 & 1.17 & 3.30 & 0.02 & 1.15 \\
\hline & Female & 3.34 & 0.02 & 1.26 & 3.24 & 0.02 & 1.20 & 3.24 & 0.02 & 1.21 \\
\hline \multirow[t]{5}{*}{ Age } & 24 or $<$ & 2.29 & 0.05 & 1.17 & 2.93 & 0.05 & 1.13 & 3.10 & 0.05 & 1.14 \\
\hline & $25-34$ & 3.36 & 0.03 & 1.19 & 3.30 & 0.03 & 1.13 & 3.26 & 0.03 & 1.13 \\
\hline & $35-44$ & 3.42 & 0.03 & 1.22 & 3.35 & 0.03 & 1.15 & 3.31 & 0.03 & 1.17 \\
\hline & $45-54$ & 3.36 & 0.04 & 1.26 & 3.28 & 0.03 & 1.22 & 3.23 & 0.03 & 1.19 \\
\hline & $55>$ & 3.40 & 0.04 & 1.30 & 3.34 & 0.04 & 1.25 & 3.38 & 0.04 & 1.24 \\
\hline
\end{tabular}

There is a distinct and clear pattern of difference based on informants' age. Overall, the data suggest that as Australian workers get older they can exercise greater discretion across all three facets of their work. However, this increase is not entirely linear, with two elements (i.e. sequence of work tasks and changing main work tasks) being most afforded to workers aged between 35 and 44 . These two measures are possibly the most salient in terms of work discretion and the problem spaces that such discretion affords. So, these data suggest that, perhaps unsurprisingly, younger workers are afforded less discretion, and, therefore, opportunities for engaging in decision-making, problemsolving and monitoring of outcomes, than their older counterparts. This likely indicates less experienced workers are not afforded the range of opportunities that more experienced workers are permitted, and perhaps expected to undertake. Evident here is that workers in the middle of their working life (i.e. 35 to 44 ) are those granted the greatest discretion and, therefore, opportunities for new or novel learning. 
Findings associated with relationships between levels of educational achievement and workplace discretion offer a clear and distinctive pattern (see Table 2).

Table 2 - Task discretion by level of educational achievement

\begin{tabular}{|c|c|c|c|c|c|c|c|c|c|c|}
\hline & & \multicolumn{9}{|c|}{ Task discretion } \\
\hline & & \multicolumn{3}{|c|}{$\begin{array}{c}\text { Extent to which you can } \\
\text { choose the sequence of } \\
\text { your work }\end{array}$} & \multicolumn{3}{|c|}{$\begin{array}{l}\text { Extent to how you can } \\
\text { change main work tasks }\end{array}$} & \multicolumn{3}{|c|}{$\begin{array}{c}\text { Extent to which you can } \\
\text { change the pace of your } \\
\text { work }\end{array}$} \\
\hline & ISCED & means & $\mathrm{Se}$ & $\mathrm{Sd}$ & means & $\mathrm{Se}$ & sd & means & $\mathrm{Se}$ & $\mathrm{sd}$ \\
\hline \multirow{8}{*}{$\begin{array}{l}\text { Highest } \\
\text { level of } \\
\text { education }\end{array}$} & 1 or less & 2.99 & 0.10 & 1.41 & 2.97 & 0.09 & 1.36 & 3.04 & 0.09 & 1.32 \\
\hline & $2,3 C$ & 3.10 & 0.04 & 1.29 & 3.02 & 0.04 & 1.28 & 3.11 & 0.04 & 1.27 \\
\hline & $3 A-B, C$ & 3.26 & 0.03 & 1.24 & 3.20 & 0.03 & 1.19 & 3.29 & 0.03 & 1.20 \\
\hline & $4 A-B-C$ & 3.43 & 0.06 & 1.24 & 3.36 & 0.06 & 1.17 & 3.35 & 0.06 & 1.18 \\
\hline & $5 B$ & 3.40 & 0.05 & 1.22 & 3.31 & 0.05 & 1.15 & 3.27 & 0.04 & 1.13 \\
\hline & $5 A \cup G$ & 3.52 & 0.03 & 1.16 & 3.44 & 0.03 & 1.08 & 3.33 & 0.03 & 1.10 \\
\hline & $5 A P G$ & 3.68 & 0.06 & 1.11 & 3.72 & 0.06 & 0.99 & 3.41 & 0.06 & 1.10 \\
\hline & 6 & 3.89 & 0.12 & 0.89 & 3.62 & 0.13 & 0.97 & 3.53 & 0.13 & 0.97 \\
\hline
\end{tabular}

Notes: ISCED 1- Primary or less; ISCED 2 - Lower secondary - 3C short; ISCED 3A-B, C long upper secondary;

ISCED 4A-B-C -Post secondary, non-tertiary; ISCED 5B Tertiary - professional degree; ISCED 5A -Tertiary Bachelor degree; ISCED 5A -- Tertiary - Master degree; ISCED 6 -Research degree

Across the three measures of worker discretion, the extent discretion is reported as being afforded to these workers aligns with informants' level of education. Those with lower levels of educational achievement report lower levels of discretion compared with those with high levels of educational achievement. The range of means for sequencing of work tasks moves from 2.99 through to 3.89 in which the difference constitutes more than a standard deviation at the highest level. Similarly, for both the ability to change work tasks (2.97 through to 3.62) and change pace of work (3.04 through to 3.53) similar distinctions are offered. Hence, a clear pattern that attributes higher levels of discretion in work activities with levels of educational achievement is presented.

Similar patterns were evident based on informants' employment. Those identifying as being an Employee report lower levels of discretion on all three measures (3.02; 2.97; 3.03 respectively), with the highest level being enjoyed by those identifying themselves as Self-employed or unpaid family worker $(3.87 ; 3.75 ; 3.69$ respectively). Employees supervising fewer than five people enjoy the second lowest level of discretion (3.50; 3.43; 3.38 respectively) compared with Employees supervising more than five people (3.62; $3.56 ; 3.42$ respectively). Consequently, different kinds of employment are also indicators of extent of discretion, and potential for learning realised by the scope of activities and decision-making they perform. It is not surprising that workers who are selfemployed and working as sole proprietors necessarily exercise high levels of discretion and agency in their work. Similar patterns were identified in small business proprietors' approach to learning a new practice (i.e. administering a goods and service tax)(Billett, Ehrich, \& Hernon-Tinning, 2003). Importantly, what appears to be indicated here is that these different forms of employment afford distinct opportunities for workers' engagement in decision-making, problem-solving and, therefore, opportunities for learning.

This conclusion is supported by two further analyses based on industry sector and occupations. In the former, higher levels of discretion were reported in some industry sectors than others. The highest levels of discretion were those associated with work in Professional, scientific and technical activities $(3.79 ; 3.64 ; 3.53$ respectively), Real estate activities $(3.78 ; 3.70 ; 3.62)$ and 
Finance and insurance activities $(3.57 ; 3.47 ; 3.53)$. The lowest levels were those from Transport and storage $(3.00 ; 2.93 ; 2.96$ respectively), Accommodation and food service activities $(3.08 ; 2.95 ; 2.98)$ and Manufacturing $(3.16 ; 3.19 ; 3.12)$. Without further data and more detailed analyses, it is not possible to draw strong conclusions from these data. Yet, it is possible to impute that the kinds of work undertaken across industry categories make these findings plausible.

Similarly, comparisons based on informants' occupations indicate patterns of discretion afforded individuals working in those roles. The highest reported levels of discretion were by those nominated as Legislators, senior officials and managers (3.93; $3.84 ; 3.63$ respectively), Skilled agricultural and fishery workers $(3.74 ; 3.64 ; 3.68)$, Professionals $(3.53 ; 3.50 ; 3.34)$ and Technicians and associate professionals $(3.59 ; 3.42 ; 3.43)$. Here again, the findings are interesting and appear plausible (i.e. they have face validity). The category of Legislators etc seems plausible, as is those associated with professional and technical work. Then, given that agricultural and fishery workers likely work in circumstances away from direct supervision and having to make decisions, such a finding also is plausible. So, taking into consideration that the practices, requirements and work organisation likely differ across industries and occupations, such differences manifest themselves in workplace discretion. This finding has implications for the scope of activities workers engage in and the potential parameters for what they will learn through their work activities.

\section{Findings associated with problem-solving activities}

Two survey items referred specifically to the frequency by which workers engaged in problemsolving activities. Firstly, those problems for whom the resolution could be found within 5 minutes and those problems requiring up to 30 minutes to identify appropriate solutions. Referring to different kinds of problem-solving activities, ones that perhaps are reasonably well-defined and those that are more complex (i.e. less well defined and understandable) they provide comparisons about the learning outcomes likely arise from these activities. Problems that can be solved readily (i.e. routine) are likely generative of reinforcement, refinement of what individuals know, can do and value and, perhaps, building of new causal links and associations in conceptual or propositional development (Groen \& Patel, 1988). Those problems requiring longer resolution might be seen as being non-routine problems. As such, they are potentially generative of new learning or making new connections amongst concepts, and eliciting new procedures and a reappraisal of values and dispositions(Glaser, 1984). Hence, it is helpful to know not only the frequency by which problems are engaged with by workers, but also the patterns of each kinds of problem solving. Again, these data were analyses using variables on informants: gender, age, educational levels, kinds of employment, industry sectors and occupations.

In Table 3 are presented the frequencies of these problem-solving activities as reported on the basis of gender and age. In this table, both kinds of problem-solving activities are reported by both genders although the frequencies are lower for non-routine than routine problem-solving and for both kinds, slightly higher levels by males than females. Identifiable patterns of responses related to categories of worker age are apparent. Workers of all ages reported engaging in both routine and non-routine problem-solving activities with the former occurring 'At least once a week' and the latter 'Less frequently than once a week, but more frequently than once a month'. Within these categories were differences in frequencies of engaging in both kinds of problem-solving activities. The most frequent level of engagement in both kinds of problem-solving are those for workers aged between 25 and 34, followed by those aged between 35 and 44. Both kinds of problem-solving activities were reported at a lower level in the early years of working career and towards the end. 
Again, the kind of reasons behind this pattern, in terms of skill development and utilisation in workplaces can be imputed.

Table 3 - Problem-solving and learning through work

\begin{tabular}{llccccccc}
\hline & \multicolumn{8}{c}{ Problem-solving } \\
\hline & & \multicolumn{2}{c}{$\begin{array}{c}\text { How often does work involves } \\
\text { confronting simple problems }\end{array}$} & \multicolumn{2}{c}{$\begin{array}{c}\text { How often work involves confronting } \\
\text { demanding problems }\end{array}$} \\
\cline { 3 - 9 } & & means & Se & sd & means & se & sd \\
\hline \multirow{2}{*}{ Gender } & Male & 4.27 & 0.02 & 1.11 & 3.24 & 0.02 & 1.29 & 1.32 \\
& Female & 4.17 & 0.02 & 1.16 & 3.03 & 0.02 & 0.05 & 1.33 \\
\hline \multirow{2}{*}{ Age } & 24 or & 4.21 & 0.04 & 1.17 & 2.75 & 0.04 & 1.26 \\
& $25-34$ & 4.34 & 0.03 & 1.05 & 3.33 & 0.03 & 1.26 \\
& $35-44$ & 4.29 & 0.03 & 1.07 & 3.28 & 0.04 & 1.32 \\
& $45-54$ & 4.21 & 0.03 & 1.16 & 3.15 & 0.04 & 1.33 \\
\hline
\end{tabular}

But, it is worthwhile to explore other analyses. For instance, there are clear patterns when data on problem-solving is compared with informants' level of qualifications. Table 4 presents data indicating an almost direct relationship between frequency of engagement in both kinds of problemsolving activities and levels of education. The higher the level of individuals' qualification, the more frequently they engaged in both kinds of problem-solving activities. The pattern is only disrupted by those at the penultimate level of educational attainment reporting a greater frequency of both kinds of problem-solving activities (i.e. 4.40 and 3.69) than those at the highest level (4.38 and 3.57). Overall, these data show that all workers beyond the lowest level of educational achievement engage in routine problem-solving 'At least once a week', whereas engagement in non-routine problem-solving for all informants, except those at the lowest two levels of education reported engaging in these activities 'Less frequently than a weekly, but more frequently than monthly'.

Table 4 - Problem-solving by levels of education

\begin{tabular}{|c|c|c|c|c|c|c|c|}
\hline & \multirow[b]{3}{*}{ ISCED } & \multicolumn{6}{|c|}{ Problem-solving } \\
\hline & & \multicolumn{3}{|c|}{$\begin{array}{l}\text { How often does work involve } \\
\text { confronting simple problems }\end{array}$} & \multicolumn{3}{|c|}{$\begin{array}{l}\text { How often is work involved confronting } \\
\text { demanding problems }\end{array}$} \\
\hline & & means & $\mathrm{Se}$ & $\mathrm{sd}$ & means & $\mathrm{Se}$ & $\mathrm{Sd}$ \\
\hline \multirow{8}{*}{$\begin{array}{l}\text { Highest } \\
\text { level of } \\
\text { education }\end{array}$} & 1 or less & 3.59 & 0.09 & 1.41 & 2.52 & 0.09 & 1.41 \\
\hline & $2,3 \mathrm{C}$ & 3.98 & 0.04 & 1.31 & 2.69 & 0.04 & 1.36 \\
\hline & $3 A-B, C$ & 4.21 & 0.03 & 1.14 & 3.00 & 0.03 & 1.31 \\
\hline & $4 A-B-C$ & 4.39 & 0.05 & 1.01 & 3.33 & 0.06 & 1.27 \\
\hline & $5 B$ & 4.36 & 0.04 & 0.99 & 3.26 & 0.05 & 1.26 \\
\hline & $5 A \cup G$ & 4.37 & 0.03 & 0.99 & 3.48 & 0.03 & 1.17 \\
\hline & 5A PG & 4.40 & 0.06 & 1.04 & 3.69 & 0.06 & 1.08 \\
\hline & 6 & 4.38 & 0.13 & 0.96 & 3.57 & 0.13 & 0.97 \\
\hline
\end{tabular}

Notes: ISCED 1- Primary or less; ISCED 2 - Lower secondary - 3C short; ISCED 3A-B, C long upper secondary; ISCED 4A-B-C -Post secondary, non-tertiary; ISCED 5B Tertiary - professional degree; ISCED 5A -Tertiary Bachelor degree; ISCED 5A -- Tertiary - Master degree; ISCED 6 -Research degree

The frequency of problem-solving activities across industries and occupations reflect those of discretion in the previous section, but are most strongly represented in occupational hierarchies. Hence, the highest frequencies of both kinds of problem-solving activities are those categorised as 
Professionals (4.47-3.67), Legislators, senior officials and managers (4.44-3.62) and Technicians and associate professionals $(4.39-3.46)$.

The frequency by forms of employment also has a distinct pattern. But unlike discretion, those with the highest frequency of both kinds of problem-solving were 'Employee, supervising more than five people' $(4.61-3.75)$, with the lowest being 'Employee, not supervisor' $(4.11-2.91)$ with the next lowest being 'Self-employed of unpaid family worker' $(4.04-3.03)$ and the second highest is 'Employee, supervising fewer than five people' (4.45-3.45). These patterns suggest some forms of employment have particular patterns of problem-solving activities with some engaging in both kinds of problem-solving activities more highly than others.

Together, these analyses also suggest that all kinds of employment require workers to engage in non-routine problem-solving on a regular basis (i.e. less frequently than once a week but more frequently than once a month). Hence, all categories of workers not only require, but likely develop higher-order capacities through their everyday work activities, as was found in qualitative studies. Put simply, these informants would be unable to perform their workplace roles without being able to address work tasks that included novel elements and requirements. Hence, this suggests that all workers require higher-order capacities to perform their work and ongoing engagement in work activities affords the opportunities to utilise higher-order capacities, which in turn promotes their further development. As such this finding replicates the findings of a study conducted by the author of workers across a range of occupations that identified little difference in requirement for non-routine problem-solving (Billett, 1994).Potentially important here are also the opportunities afforded for the development of causal links and associations - propositional links that are central to expert performance and are exercised through selecting, enacting and monitoring appropriate procedures. These are the kinds of learning experiences and outcomes that schoolbased instructional efforts seek to provide and secure. That is, everyday work experiences appear to potentially provide the kind of experiences that promote the development of causal links and associations among propositions that is central to the development of deep understanding. This is because, depth of knowledge is characterised by links and associations and the strength and complexities propositional of these associations (Groen \& Patel, 1988). Moreover, problem-solving activities of a non-routine kind is important in refining and honing procedures (i.e. how we do things), and building these links and associations, and also refining and transforming learners' dispositions. That is, they provide the opportunities to practice, which lead to proceduralisation (J R. Anderson, 1982), and build the kinds of propositional links (Prawat, 1989) required for deep understanding. They also shape how we direct our energies and capacities when engaging in goaldirected activities such as work, and the learning that arises from it. So, it is not just a question of learning arising through these experiences, but the particular kinds of learning that arise through these problem-solving processes.

\section{Findings associated with learning experiences}

Two survey items specifically aimed to elicit responses about how frequently informants learned through: i) engaging with more experienced or expert co-workers or others, and ii) personally mediated learning arising through their work. As noted, earlier studies found the key contributions to learning through work activities (i.e. engaging in everyday work activities, opportunities to practice and refine, in direct guidance provided by more expert partners and direct guidance by more expert partners), with only one primarily premised upon the actions of more experienced others (Billett, 2001). The other three are premised on how individuals engage in their work and 
learning: i.e. the degree by which they rehearse and refine what they do, and act interdependently with other workers, artefacts etc (Billett, 2014a). So, whilst much is made of teaching, mentoring, direct guidance by more experienced co-workers, supervisors or workplace trainers, the qualitative evidence suggests that these are not necessarily the key contributions to learning through work.

Quantitative analyses of frequencies of these two types of learning processes are potentially helpful in illuminating this issue. Here, are provided descriptive analyses between these two forms of mediation (i.e. workplace and personal) and variables of workers' age, levels of education, kinds of employment, industry sectors in which they work and their occupations. Overall, informants report learning through performing their work to be more frequent than that provided when guided by coworkers and supervisors. In one way, this proposition is plausible given that workers learn all of the time, not just when they are being supervised or guided in their work. However, it is important that the contribution of this mode of learning is identified, because of assumptions mentioned above about the privileging of learning arising from being taught or guided by others. Put simply, the kinds and exercise of discretion in problem-solving that leads to learning as emphasised in the previous sections are seemingly rehearsed and supported in finding of this section. That is, learning of which informants are conscious arising through their work occurs more frequently than when being taught. In each of the tables in this section, a column has been inserted which calculates the differences in the means between the two reported frequencies of mode of learning. This difference is always positively arrayed in favour of learning by doing through performing the informants' work. So, how does this pattern play across these analyses?

Table 5 presents data for learning at work by comparing the two forms of mediation of learning (i.e. personally and by others) against informants' age. As with the other tables, the key columns relate to the particular phenomena being analysed. In this case, the data from items associated with: i) how the informants learnt from their co-workers and supervisors and ii) how often they learnt through performing their job. The right hand column provides the difference between the two means.

Table 5 Processes of learning by age

\begin{tabular}{|c|c|c|c|c|c|c|c|c|}
\hline & \multicolumn{8}{|c|}{ Learning at work } \\
\hline & & \multicolumn{3}{|c|}{$\begin{array}{c}\text { How often you learn from co- } \\
\text { workers and supervisors }\end{array}$} & \multicolumn{3}{|c|}{$\begin{array}{l}\text { How often job involves learning by } \\
\text { doing through performing job }\end{array}$} & \multirow[b]{2}{*}{ Diff mean } \\
\hline & & means & se & $\mathrm{sd}$ & means & se & $\mathrm{sd}$ & \\
\hline \multirow[t]{5}{*}{ Age } & 24 or $<$ & 3.74 & 0.05 & 1.16 & 4.02 & 0.05 & 1.20 & 0.28 \\
\hline & $25-34$ & 3.59 & 0.03 & 1.17 & 3.94 & 0.03 & 1.14 & 0.35 \\
\hline & $35-44$ & 3.37 & 0.03 & 1.25 & 3.76 & 0.03 & 1.27 & 0.39 \\
\hline & $45-54$ & 3.19 & 0.04 & 1.31 & 3.70 & 0.04 & 1.33 & 0.51 \\
\hline & $55>$ & 3.01 & 0.04 & 1.37 & 3.45 & 0.04 & 1.46 & 0.44 \\
\hline
\end{tabular}

The clear pattern in this table is of a higher frequency of learning experiences of both kinds being inversely associated with age. That is, the younger the workers, the more both kinds of learning experiences are reported. Hence, the means for workers aged 24 or less is 3.74 and 4.02 respectively, whereas for workers aged 55 and over it is 3.01 and 3.45 respectively. The overall agerelated pattern is that the difference between the two means is smaller for the younger workers $(0.28)$ and these reported instances increase with age, albeit peaking for workers in the 45 to 54 year age category (0.51) which almost equates to half a standard deviation. These findings can be imputed to propose that younger workers are more likely to be learning their occupation and, hence, report higher levels of both kinds of learning experiences, and are conscious of their new 
learning. Older workers are still continuing to learn, but their reliance upon more experienced coworkers and supervisors is probably lower and ability to mediate their own learning is stronger. Yet, even for younger workers, learning through work is reported more frequently than when being assisted by others (co-workers and supervisors).

So, workers of all ages report identifiable learning experiences through work and these are ongoing across working lives (i.e. reported by workers of all ages). Moreover, evident here is the proposition that workers' personally-mediated everyday experiences such as that identified qualitatively (Billett, 2014a) are the key source of their learning, regardless of age. Yet, this is not to suggest that being guided by more experienced co-workers and supervisors is unimportant or that they cannot make essential contributions. Clearly, there is much knowledge that individuals cannot learn through discovery or personal mediation alone, or it would take unhelpfully long periods of time and the unnecessary exertion of effort to do so. However, it may well provide evidence of the central role of individuals' personally mediated construal and construction of knowledge is central to learning through work and across working life, which was found in the qualitative studies (Billett, 2001).

A different pattern is evident in comparisons between these two modes of learning and informants' education levels. In Table 6, the overall finding about frequency of personally-mediated learning through work is upheld and for workers of all levels of educational achievement. However, there is a clear alignment between levels of education and reported frequencies for both categories of learning modes. Informants with higher levels of qualifications report both modes far more frequently than those with lower levels of qualifications. For learning from co-workers and supervisors, the means for those at the lowest educational level (2.87) is distinct from those at the higher levels, with those with undergraduate degrees having a mean of 3.60. . Similarly, for learning through work the mean for informants with lower secondary education is 3.29 whereas those with a masters degree is 3.92 .

Table 6 Processes of learning by levels of education

\begin{tabular}{|c|c|c|c|c|c|c|c|c|}
\hline & \multicolumn{8}{|c|}{ Learning at work } \\
\hline & \multirow[b]{2}{*}{ ISCED } & \multicolumn{3}{|c|}{$\begin{array}{c}\text { How often you learn from co- } \\
\text { workers and supervisors }\end{array}$} & \multicolumn{3}{|c|}{$\begin{array}{l}\text { How often job involves } \\
\text { learning by doing through } \\
\text { performing job }\end{array}$} & \multirow[b]{2}{*}{$\begin{array}{l}\text { Diff } \\
\text { mean }\end{array}$} \\
\hline & & means & $\mathrm{Se}$ & $\mathrm{Sd}$ & means & $\mathrm{Se}$ & $\mathrm{sd}$ & \\
\hline \multirow{8}{*}{$\begin{array}{l}\text { Highest } \\
\text { level of } \\
\text { education }\end{array}$} & 1 or less & 2.87 & 0.11 & 1.47 & 3.29 & 0.11 & 1.58 & 0.42 \\
\hline & $2,3 C$ & 3.12 & 0.05 & 1.37 & 3.58 & 0.05 & 1.45 & 0.46 \\
\hline & $3 A-B, C$ & 3.33 & 0.03 & 1.32 & 3.77 & 0.03 & 1.31 & 0.44 \\
\hline & $4 A-B-C$ & 3.32 & 0.07 & 1.33 & 3.69 & 0.07 & 1.33 & 0.37 \\
\hline & $5 B$ & 3.35 & 0.05 & 1.2 to & 3.84 & 0.05 & 1.23 & 0.49 \\
\hline & $5 A \cup G$ & 3.60 & 0.03 & 1.12 & 3.87 & 0.03 & 1.16 & 0.27 \\
\hline & $5 A P G$ & 3.55 & 0.07 & 1.14 & 3.92 & 0.06 & 1.15 & 0.37 \\
\hline & 6 & 3.50 & 0.15 & 1.05 & 3.91 & 0.15 & 1.08 & 0.14 \\
\hline
\end{tabular}

Again, there are considerable differences, when reported over such a large sample. Those with higher levels of education are afforded greater levels of learning support at work and are afforded opportunities for higher levels of learning through their work. These findings are consistent with patterns from the previous section reporting factors of work associated with discretion and problem-solving. So, here it would seem that levels of educational achievement are affirmed as a predictor of opportunities for learning through work and across working life. 
Findings from a comparative analysis of informants' kinds of employment also offer a pattern of learning experience frequencies. In Table 7, the data comparing the two kinds of learning modes with categories of employment, not surprisingly, show that learning through everyday work is reported as occurring more frequently than when supported by more experienced others. This is not surprising because it would be anticipated that these means would need to be exercised in a work setting where workers would largely be expected to perform work without close supervision.

Table 7 - Learning processes by Occupational status

\begin{tabular}{|c|c|c|c|c|c|c|c|c|}
\hline & & \multicolumn{6}{|c|}{ Learning at work } & \multirow[b]{3}{*}{$\begin{array}{r}\text { Diff } \\
\text { mean }\end{array}$} \\
\hline & & \multicolumn{3}{|c|}{$\begin{array}{l}\text { How often you learn from } \\
\text { co-workers and supervisors }\end{array}$} & \multicolumn{3}{|c|}{$\begin{array}{l}\text { How often job involves } \\
\text { learning by doing } \\
\text { through performed in job }\end{array}$} & \\
\hline & & Means & se & $\mathrm{Sd}$ & means & se & sd & \\
\hline \multirow[t]{4}{*}{$\begin{array}{l}\text { Occupational } \\
\text { status }\end{array}$} & $\begin{array}{l}\text { Employee, not } \\
\text { supervisor }\end{array}$ & 3.36 & 0.03 & 1.31 & 3.79 & 0.03 & 1.33 & 0.43 \\
\hline & $\begin{array}{l}\text { Employee, supervising } \\
<5 \text { people }\end{array}$ & 3.40 & 0.04 & 1.20 & 3.84 & 0.04 & 1.22 & 0.44 \\
\hline & $\begin{array}{l}\text { Employee, supervising } \\
\text { 5> people }\end{array}$ & 3.56 & 0.04 & 1.13 & 3.80 & 0.04 & 1.22 & 0.24 \\
\hline & $\begin{array}{l}\text { Self-employed or } \\
\text { unpaid family worker }\end{array}$ & 2.81 & 0.07 & 1.31 & 3.50 & 0.05 & 1.37 & 0.69 \\
\hline
\end{tabular}

Also, not surprisingly, the lowest frequency for being guided by those others is reported by informants categorised as being Self-employed or on paid family worker (2.81). Those categorised as being 'Employees, not supervisors' report the next lowest level (i.e. 3.36, with 'Employees supervising fewer than five people' (3.40) and Employee supervising more than five people the highest level of frequency at 3.56. So, taking those who are employed, the highest frequency of being guided is for higher-level supervisors and the lowest level for employees. A similar pattern then follows in the reported frequency of learning through work, with Self-employed being the least frequent (3.50) followed by those who are Employees (3.79) and the highest is Employees who supervise fewer than five people (3.84) with Employee supervising more than five people having a mean of 3.80. The surprise here is the relatively low frequency reported by Self-employed workers about learning through their job (i.e. personally-mediated), which might have been anticipated to report a high frequency of this mode of learning, as was the case in an earlier qualitative study of small business operators (Billett et al., 2003). Yet, the frequencies based on informants' industry sectors and occupations, emphasise the same overall pattern of reported mediation of learning. In all, these analyses, on the one hand, strongly support the conclusions drawn from the earlier and qualitative studies, about learning through work, yet indicate how the activities that are likely to support that learning are distributed in distinct ways across this large cohort of worker informants.

\section{Work, discretion and learning}

There is a need for individuals in occupations of all kinds to continue to learn across their working lives as work requirements change, workplace practices transform and occupational requirements evolve in response to innovations, and as technologies and requirements for goods and service change. What these data establish is that workplace experiences provide a range of opportunities for workers' learning and these are not restricted to the reinforcement and refinement of what individuals already know, can do and value. The work activities identified in these data indicate that 
workplace learning experiences are well aligned to developing higher-order capacities, such as strategic procedures and deepening of individuals' conceptual knowledge and the honing and refinement of their values. Most powerfully, what these data indicate are frequencies by which opportunities for learning arise for all kinds of workers, albeit asynchronously, through everyday work activities and interactions. This mode of learning is proposed as being more frequent through everyday learning experiences and as reported here are likely to contribute to the development of higher order procedures, deeper conceptual capacities and nuanced vales. This conclusion is analogous to what qualitative studies have found earlier, as noted above.

In the analysis advanced here, two key measures: i) work discretion and ii) problem-solving support and reinforce this proposition. The degree of individuals' discretion have in their work delineates the kind and extent of problem-solving activities and scope of the problem space with which they negotiate. This discretion is something exercised through everyday work activities, and not reserved for interludes intentionally associated with learning and development. Moreover, this kind of activity is associated with individuals' learning new knowledge and its monitoring, appraisal and further development. Then, responses to two kinds of problem solving activities are reported as providing indications of how those encountered in work life that reinforce and extend what individuals know, can do and value, and also those that can transform their knowledge as they engage in demanding problem-solving activities. So, these findings support, consolidate and verify much of what has been proposed through qualitative studies about learning through work.

However, the findings also offer patterns of evidence about who is afforded opportunities to learn and develop further their knowledge through the kinds of activities they are able to engage in across their working lives. These opportunities are asymmetrically distributed. For instance, measures such as age, level of educational achievement and occupation indicate distinct patterns of discretion and engagement in problem-solving activities. A male aged between 33 and 45, with higher levels of education and in a professional or paraprofessional occupation is perhaps granted the most opportunities for learning through their work. Then, if that male is self-employed they are likely to have the most extensive array of discretion and, therefore, learning through their work. Perhaps none of this is particular new or surprising. However, these data sets out clear patterns associated with the distribution of experiences afforded workers on the basis of age, highest educational achievement, occupation, industry sector and occupational status. So, what is afforded workers in terms of opportunities for learning is highly differentiated across workforces, albeit in ways that are not surprising. Yet, by identifying these factors, it is possible to propose means by which learning through work can be more broadly engaged with and, in particular, how higher forms of learning through broadening discretion and engaging in non-routine problem-solving can be secured through the organisation and enactment of workplace practices. This has been achieved through a basic descriptive quantitative analysis in ways that could not have been advanced through qualitative inquiry alone.

Hence, this analysis of the Australian PIAAC data indicates how helpful it is to bring together qualitative and quantitative inquiries focussing on the same kind of issues and whose focuses, processes and findings can be constructive and complementary.

\section{Acknowledgement}

Dan Cummings assisted with organising the Australian PIAAC data in ways that made them workable and has supported and provided advice on the analysis presented here. Also, it is important to acknowledge the impetus and support provided by being an international advisor on the SkillsReal 
project, funded by the Norwegian Research Council and led by Tarja Tikkanen from Høgskolen Stord/Haugesund in Norway.

\section{References}

Anderson, J. R. (1982). Acquisition of cognitive skill. Psychological Review, 89(4), 369-406.

Anderson, J. R. (1993). Problem solving and learning. American Psychologist, 48(1), 35-44.

Australian Bureau of Statisics. (2013). Programme for the International Assessment of Adult Competencies (Australia 2011-2012) In A. B. o. Statisics (Ed.), Cat 42280.0. Canberra.

Bijou, S. W. (1990). History and Educational Applications of Behaviouralism. In R. M. Thomas (Ed.), The Encyclopedia of Human Development and Education Theory, Research, and Studies. Oxford: Pergamon Press.

Billett, S. (1994). Situated Learning - a workplace experience. Australian Journal of Adult and Community Education, 34(2), 112-130.

Billett, S. (2001). Learning in the workplace: Strategies for effective practice. Sydney: Allen and Unwin.

Billett, S. (2003). Sociogeneses, Activity and Ontogeny. Culture and psychology, 9(2), 133-169.

Billett, S. (2006). Relational interdependence between social and individual agency in work and working life. Mind, Culture and Activity, 13(1), 53-69.

Billett, S. (2009). Conceptualising learning experiences: Contributions and mediations of the social, personal and brute. Mind, Culture and Activity, 16(1), 32-47.

Billett, S. (2014a). Mediating learning at work: Personal mediations of social and brute facts „, . In C. Harteis, A. Rausch, \& J. Seifried (Eds.), Discourses on Professional Learning: On the Boundary between Learning and Working. Dordrecht: Springer, The Netherlands.

Billett, S. (2014b). Mimesis: learning through everyday activities and interactions at work, . Human Resource Development Review 13 (4), 462-482.

Billett, S., Ehrich, L., \& Hernon-Tinning, B. (2003). Small business pedagogic practices. Journal of Vocational Education and Training, 55(2), 149-167.

Engestrom, Y. (1993). Development studies of work as a testbench of activity theory: The case of primary care medical practice. In S. Chaiklin \& J. Lave (Eds.), Understanding Practice: perspectives on activity and context (pp. 64-103). Cambridge, U.K: Cambridge University Press.

Eraut, M. (2004). Informal learning in the workplace. In H. Rainbird, A. Fuller, \& A. Munro (Eds.), Workplace Learning in context. London: Routledge.

Fuller, A., \& Unwin, L. (2004). Expansive learning environments: Integrating organisational and personal development. In H. Rainbird, A. Fuller, \& A. Munroe (Eds.), Workplace learning in context (pp. 126-144). London: Routledge.

Gauvain, M. (1993). The development of spatial thinking in everyday activity. Development Review, 13(1), 92-121.

Gergen, K. J. (1994). Realities and relationships: Soundings in social construction. Cambridge, Mass: Harvard University Press.

Glaser, R. (1984). Education and thinking - the role of knowledge. American Psychologist, 39(2), 93104.

Glaser, R. (1989). Expertise and learning: How do we think about instructional processes now that we have discovered knowledge structures? In D. Klahr \& K. Kotovsky (Eds.), Complex information processing: The impact of Herbert A. Simon (pp. 289-317). Hillsdale, NJ: Erlbaum \& Associates.

Greeno, J. G., \& Simon, H. A. (1988). Problem solving and reasoning. In R. C. Aitkinson, R. J. Hormiston, G. Findeyez, \& R. D. Yulle (Eds.), Steven's handbook of experimental psychology and education, Vol 2. New York: Wiley. 
Groen, G. J., \& Patel, P. (1988). The relationship between comprehension and reasoning in medical expertise. In M. T. H. Chi, R. Glaser, \& R. Farr (Eds.), The Nature of Expertise (pp. 287-310). New York: Erlbaum.

Guberman, S. R., \& Greenfield, P. M. (1991). Learning and transfer in everyday cognition. Cognitive Development, 6, 233-260.

Lave, J. (1993). The practice of learning. In S. Chaiklin \& J. Lave (Eds.), Understanding practice: Perspectives on activity and context (pp. 3-32). Cambridge, UK: Cambridge University Press.

Marsick, V. J., \& Watkins, K. (1990). Informal and incidental learning in the workplace. London: Routledge.

Mayer, R. E. (1992). Thinking, problem solving, cognition (2nd ed.). A series of books in psychology. New York, NY, US: W H Freeman/Times Books/ Henry Holt \& Co.

Newell, A., \& Simon, H. A. (1972). Human problem solving. Englewood Cliffs, N.J: Prentice Hall.

Organisation for Economic Co-operation and Development. (2006). Live longer, work longer: A synthesis report. Paris: OECD.

Prawat, R. S. (1989). Promoting access to knowledge, strategy, and dispositions in students: A research synthesis. Review of Educational Research, 59(1), 1-41.

Rainbow, H., Fuller, A., \& Munroe, A. (Eds.). (2004). Workplace learning in context. London: Routledge.

Ratner, C. (2000). Agency and culture. Journal for the Theory of Social Behaviour, 30, 413-434.

Reber, A. S. (1989). Implicit learning and tacit knowledge. Journal of Experimental Psychology, 118(3), 219-235.

Rogoff, B. (1990). Apprenticeship in thinking - cognitive development in social context. New York: Oxford University Press.

Rogoff, B., \& Gauvain, M. (1984). The cognitive consequences of specific experiences - weaving versus schooling among the Navajo. Journal of Cross-Cultural Psychology, 15(4), 453-475.

Rogoff, B., \& Lave, J. (Eds.). (1984). Everyday cognition: Its development in social context. Cambridge, Mass: Harvard University Press.

Schutz, A. (1996). Collected papers vol. 4. Dordrecht, The Netherlands: Kluwer Academic Publishers.

Scribner, S. (1985a). Knowledge at work. Anthropology and Education Quarterly, 16, 199-206.

Scribner, S. (1985b). Vygostky's use of history. In J. V. Wertsch (Ed.), Culture, communication and cognition: Vygotskian perspectives (pp. 119-145). Cambridge, UK: Cambridge University Press.

Shuell, T. J. (1990). Phases of meaningful learning. Review of Educational Research, 60(4), 531-547.

Tynjala, P. (2008). Perspectives into learning in the workplace. Education Research Review, 3(2), 130154.

Valsiner, J. (2000). Culture and human development. London: Sage Publications.

Valsiner, J., \& van der Veer, R. (2000). The social mind: The construction of an idea. Cambridge, UK: Cambridge University Press.

Voss, J. F. (1987). Learning and transfer in subject matter learning: a problem-solving model. International Journal of Educational Research, 11(6), 607-622.

Wertsch, J. V. (1998). Mind as action. New York: Oxford University Press. 